\title{
Review
}

International Axchives of
Allergy
Immunology

\section{In vitro Diagnosis of Immediate Drug Hypersensitivity: Should We Go with the Flow?}

\author{
Evelyne A. Mangodt ${ }^{a}$ Athina L. Van Gasse ${ }^{a}$ Ine Decuyper ${ }^{a}$ Astrid Uyttebroek ${ }^{a}$ \\ Margaretha A. Faber ${ }^{a}$ Vito Sabato ${ }^{a}$ Chris H. Bridts $^{a}$ Margo M. Hagendorens ${ }^{b}$ \\ Didier G. Ebo ${ }^{a}$
}

Departments of ${ }^{a}$ Immunology-Allergology-Rheumatology and ${ }^{b}$ Pediatrics, Faculty of Medicine and Health Science,

University of Antwerp, Antwerp University Hospital, Antwerp, Belgium

\section{Key Words}

Basophil activation $\cdot$ Flow cytometry $\cdot$ HistaFlow $^{\circledR}$.

Immunoglobulin E $\cdot$ Immediate drug allergy

\section{Abstract}

Background: Diagnosis of immediate drug hypersensitivity reactions (IDHRs) is based upon history taking, skin prick or intradermal tests and quantification of specific immunoglobulin E (lgE) antibodies. Unfortunately, this is often insufficient to correctly identify patients with IgE-mediated IDHRs and is impossible in the case of non-IgE-mediated IDHRs. Drug provocation tests (DPT) are considered the 'gold standard' diagnostic but are not always possible, for ethical and practical reasons. Therefore, the validation of new cellular tests such as basophil activation testing (BAT) was necessary. This review focuses on the applications of BAT in IDHRs. Methods: A literature search was conducted, using the words basophil, flow cytometry, immediate drug allergy and drugs; this was complemented by the authors' own expertise. Results: BAT/HistaFlow ${ }^{\circledR}$ is a useful diagnostic tool in IDHRs, mainly used to diagnose allergy to neuromuscular blocking agents (NMBAs), antibiotics, nonsteroidal anti-in- flammatory drugs (NSAIDs) and iodinated radiocontrast media. Its sensitivity varies between 50 and $60 \%$, and specificity attains $80 \%$, except for with quinolones and NSAIDs. Conclusions: The diagnostic utility of BAT (and to lesser extent HistaFlow) has been demonstrated and is mostly applied in IDHRs. However, larger-scale collaborative studies are necessary to optimize test protocols and validate the entry of BAT as a diagnostic instrument in drug allergy.

(c) 2015 S. Karger AG, Base

\section{Introduction}

Although drug provocation tests (DPT) are considered the 'gold standard' diagnostic for immediate drug hypersensitivity reactions (IDHRs), such tests are impeded by the risk of life-threatening reactions and might even be contraindicated (i.e. in patients on beta-blockers or ACE-inhibitors) or, simply, be impossible [i.e. in patients with hypersensitivity to neuromuscular blocking agents (NMBAs)]. Besides, DPT do not exhibit absolute predictive values. DPT have not entered routine clinical practice. Diagnosis of IDHRs generally starts with a thor-

\section{KARGER 125}

(c) 2015 S. Karger AG, Base

$1018-2438 / 15 / 1681-0003 \$ 39.50 / 0$

E-Mail karger@karger.com

www.karger.com/iaa
Correspondence to: Dr. Didier G. Ebo

Department of Immunology-Allergology-Rheumatology Faculty of Medicine and Health Science, University of Antwerp Campus Drie Eiken T5.95, Universiteitsplein 1, BE-2610 Antwerpen (Belgium) E-Mail immuno@uantwerpen.be 
ough history-taking complemented by skin prick tests (SPT) or intradermal testing (IDT) and/or quantification of specific immunoglobulin E (sIgE) antibodies when an IgE-mediated activation of mast cells and basophils is suspected. Unfortunately, only a very small number of drug-sIgE assays are available and almost none have been clinically validated. In addition, it has to be kept in mind that IDHRs with release of mediators by circulating basophils and tissue resident mast cells do not involve IgE/ FceRI-cross-linking per se, but might result from alternative mechanisms that are undetectable by sIgE antibody assays. The latter reinforces the need for the development and validation of new cellular tests such as basophil activation testing (BAT). These tests can indeed be informative for IDHRs that are basophil-mediated and IgE-independent. This review focuses on the current applications of BAT in IDHRs. Starting with the authors' expertise, some misconceptions, shortcomings and unmet needs in in vitro IDHR diagnosis are highlighted as well. As with any subject attended by many questions, the alternative interpretations and some explanations or hypotheses expressed here may not find universal acceptance.

\section{Basophils and Mast Cells}

Basophils represent less than $1 \%$ of the peripheral blood leukocytes. They develop from CD34+ pluripotent progenitor stem cells and exhibit a segmented nucleus. They are identifiable by metachromatic staining with basic dyes (e.g. toluidine blue). Together with tissue-resident mast cells, basophils can be triggered in ways that are IgE-dependent and IgE-independent. Cross-linking of the surface-bound high-affinity IgE receptor (FceRI) will generally occur via (glyco)proteins, chemical allergens or autoantibodies mounted against the FceRI or membrane-bound IgE antibodies. If not IgE-dependent, activation will mainly result from the coupling of receptors with endogenous (e.g. cytokines, anaphylatoxins, chemokines, IgG and neuropeptides) or exogenous (e.g. pathogen-associated molecular patterns) substances. However, degranulation of basophils and mast cells can also result from other, largely unknown mechanisms (e.g. direct mast cell degranulation by opiates, iodinated contrast media, vancomycin and quinolones). Upon activation, basophils and mast cells will release a myriad of mediators that are responsible for early- and late-phase manifestations of the immediate allergic reaction.

\section{BAT and HistaFlow ${ }^{\circledR}$}

The foundations of current flow-assisted BAT were laid a quarter of a century ago [1]. In the meantime, the technique has completely supplanted mediator-release assays that rely upon quantification of mediators released in the supernatant. The principles and requirements of BAT have been detailed elsewhere [2]. Traditional BAT relies on a flow cytometric analysis of activation and degranulation markers on the surface membrane. These changes can be detected and quantified on a single-cell level using specific monoclonal antibodies conjugated with different LASER-excitable fluorochromes. For example, basophils are traditionally identified by markers such as CCR3 (CD193)/CD3, CD123/HLA-DR or IgE/ CD203c. Of these markers, only CD203c, the ectonucleotide pyrophosphatase/phosphodiesterase family member 3 enzyme (E-NPP3), is lineage-specific. After activation, the appearance or upregulation of surface activation and/ or degranulation markers, such as CD63 and/or CD203c, is quantified. Alternative methods to quantify basophil activation imply quantification of the expression of surface inhibitory receptors such as CD300a [3], the phosphorylation of signaling molecules such as p38 mitogenactivated protein kinase (MAPK) [4] and signal transducer and activator of transcription 5 (STAT5) [5]. In addition, it was recently shown that histamine release can be quantified with flow cytometry. In this technique, designated as HistaFlow, the intracellular content of histamine and its release are analyzed by an enzyme affinity method using the histaminase diamine oxidase $[6,7]$. Figure 1 and figure 2 show a HistaFlow dotplot of a cefazolinreactive patient. Unlike the basophils of the patient displayed in figure 2, the cells of the patient in figure 1 display an anaphylactic degranulation with the appearance of CD63 and release of histamine.

\section{BAT and HistaFlow in Immediate Drug Hypersensitivity}

For about a decade now, BAT is being increasingly and successfully incorporated into the diagnostic management of IDHRs. As displayed in tables, the technique has mainly been applied to document allergy to NMBAs (table 1) [8-16], antibiotics like $\beta$-lactam antibiotics and quinolones (table 2) [17-30], aspirin and other nonsteroidal anti-inflammatory drugs (NSAIDs; table 3) [3145], and iodinated radiocontrast media (RCM; table 4) [46-48]. In general, the sensitivity of the assay varies be- 

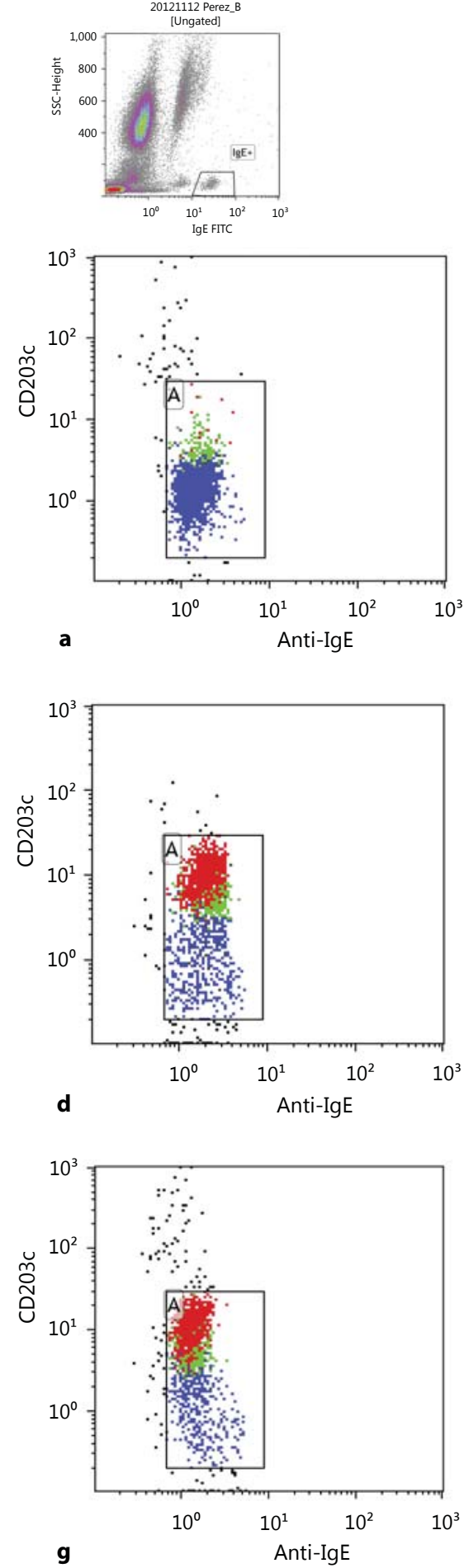
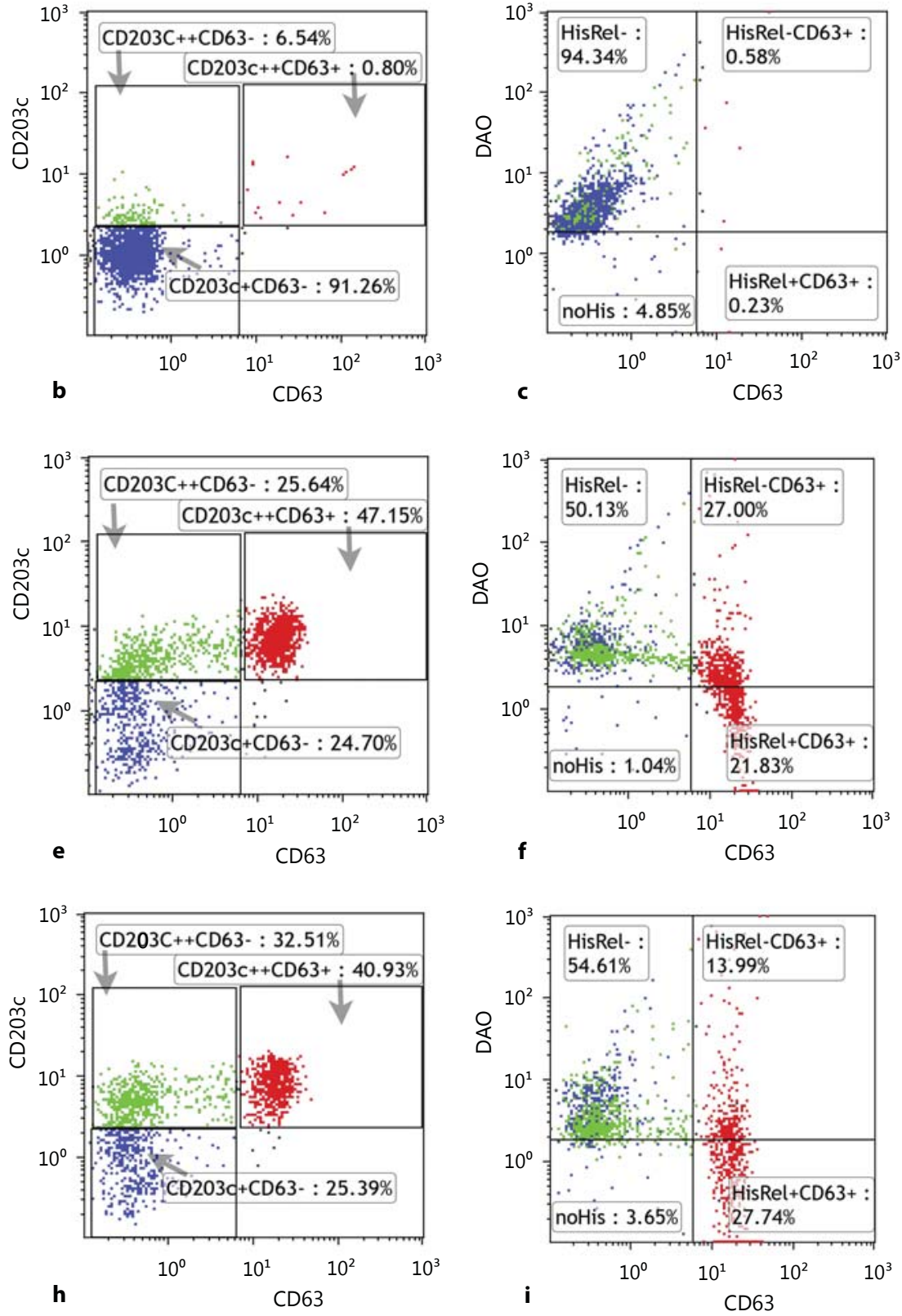

Fig. 1. HistaFlow plots in a cefazolin-reactive patient showing clear degranulation of basophils in response to cefazolin $(100 \mu \mathrm{g} / \mathrm{ml})$. a-c Quiescent cells stimulated with buffer. d-f Responses to positive control stimulation with anti-IgE. $\mathbf{g}-\mathbf{i}$ Response upon stimulation with the antibiotic. Note that only CD203c++CD63+ cells release histamine (decrease of DAO, $\mathbf{c}, \mathbf{f}, \mathbf{i}$ ).

In vitro Diagnosis of Immediate Drug Hypersensitivity
Int Arch Allergy Immunol 2015;168:3-12 DOI: $10.1159 / 000440663$ 


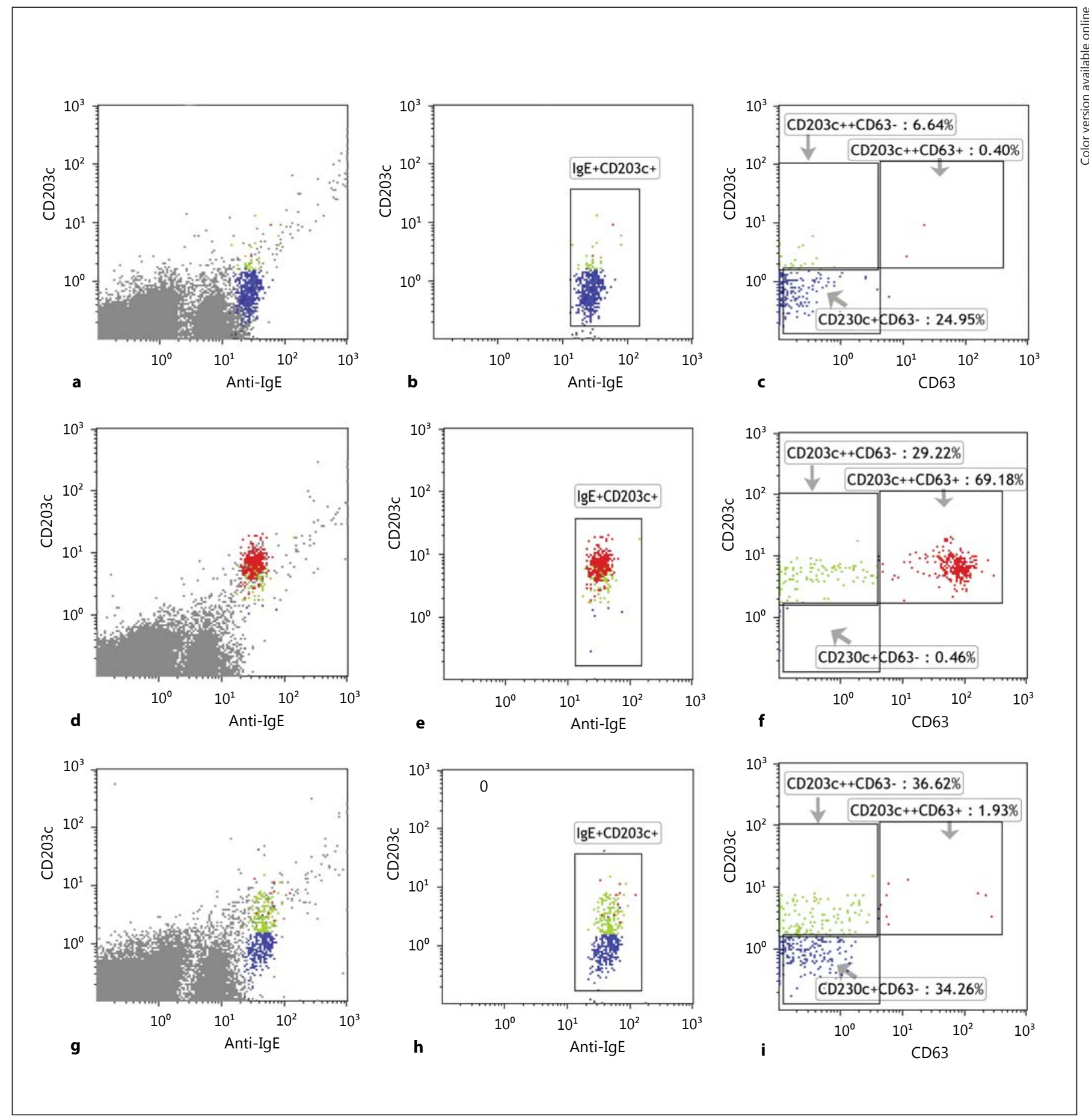

Fig. 2. HistaFlow plots in a cefazolin-reactive patient showing only activation of basophils (no clear anaphylactic degranulation of cells in response to $100 \mu \mathrm{g} / \mathrm{ml}$ cefazolin). a-c Quiescent cells stimulated with buffer. d-f Responses to positive control stimulation with anti-IgE. g-i Response upon stimulation with the antibiotic. Note that there was only upregulation of CD203c (CD203c++CD63- cells). No release (decrease of DAO) could be measured (data not shown). $\mathbf{a}, \mathbf{d}, \mathbf{g}$ are the same as $\mathbf{b}, \mathbf{e}, \mathbf{h}$ but ungated, showing the clear isolation of basophils. 
Table 1. BAT in immediate NMBA hypersensitivity

\begin{tabular}{|c|c|c|c|c|c|c|}
\hline Stimulus & Reference test & Activation marker & Sensitivity, \% & Specificity, \% & $\mathrm{N}$ & Ref. \\
\hline \multirow[t]{2}{*}{ Various NMBAs } & \multirow[t]{2}{*}{$\mathrm{H}$} & CD63 & 64 & 81 & \multirow[t]{2}{*}{26} & \multirow[t]{2}{*}{8} \\
\hline & & CD45 & 43 & 96 & & \\
\hline Various NMBAs & $\mathrm{H} \pm \mathrm{ST}$ & CD63 & 54 & 100 & 56 & 9 \\
\hline \multirow[t]{2}{*}{ Various NMBAs } & \multirow[t]{2}{*}{$\mathrm{H}$} & CD63 & 79 & 100 & \multirow[t]{2}{*}{31} & \multirow[t]{2}{*}{10} \\
\hline & & CD203c & 36 & 100 & & \\
\hline Various NMBAs & $\mathrm{H} \pm \mathrm{ST}$ & CD63 & $36-86^{1}$ & 93 & 92 & 11 \\
\hline Rocuronium & $\mathrm{H} \pm \mathrm{ST}$ & CD63 & $92^{2}$ & 100 & 22 & 12 \\
\hline Various NMBAs & $\mathrm{H} \pm \mathrm{ST} \pm \mathrm{IgE}$ & CD63 & 60 & 100 & 49 & 13 \\
\hline Rocuronium & $\mathrm{H}$ & CD63 & 80 & 96 & 104 & 14 \\
\hline Various NMBAs & $\mathrm{H}+\mathrm{ST}$ & CD63 & 68 & 100 & 56 & 15 \\
\hline Atracurium & $\mathrm{H} \pm \mathrm{ST}$ & CD63 & $71^{3}$ & 100 & 75 & 16 \\
\hline
\end{tabular}

$\mathrm{H}=$ History; $\mathrm{N}=$ number of patients and control individuals; $\mathrm{ST}=$ skin test.

${ }^{1}$ When only the reactions that occurred during the 3 years were taken into account, sensitivity increased. ${ }^{2}$ Taking into account the nonresponders, sensitivity was $76 \% .{ }^{3}$ Taking into account the nonresponders, sensitivity was $63 \%$.

tween 50 and $60 \%$, whereas specificity easily attains $80 \%$, except for quinolones and NSAIDs (see below). From some of these studies, it seems that BAT/HistaFlow allows a simultaneous testing of different compounds including both active components and excipients such as Cremophore EL [49] and clavulanic acid in amoxicillin/ clavulanic acid [50].

Apart from testing drugs, BAT seems to also be useful for testing related compounds such as antiseptics (e.g. chlorhexidine [51]), dyes (e.g. patent blue [52]), plasmaexpanders (e.g. succinylated gelatin [53] and hydroxyethyl starch [54]).

Importantly, BAT not only facilitates identification of the culprit drug but also provides the opportunity to study cross-reactivity and the tailoring of safe alternatives for the future. For example, we have observed the contribution of BAT in the study of cross-reactivity amongst NMBAs. Here, a technique was demonstrated to complement skin testing in identifying the cross-reactivity of aminosteroid and benzylisoquinoline NMBAs [12, $14,16]$.

We recently showed that the HistaFlow technique can be applied to demonstrate histamine release induced by small chemicals such as drugs. Although HistaFlow will probably not enter mainstream diagnostic application, the technique might constitute an important research asset for future studies on the pathomechanisms of IDHRs. However, larger studies are necessary to confirm its potential as, for the time being, the largest series about
HistaFlow in IDHRs comprises only 10 patients who suffered from anaphylaxis to rocuronium [55].

Another recently published asset of BAT/Histaflow is the possibility to predict safe administration of codeine, which is structurally similar to pholcodine, in patients with an allergy to the antitussive pholcodine [56]; until these results emerged, skin testing and quantification of sIgE antibodies were unable to do this. It remains to be established in larger collaborative studies whether this indicates that such basophil experiments constitute a breakthrough in genuine opiate hypersensitivity. Recently, we observed that the opiates morphine and codeine do not trigger basophil degranulation in opiate-tolerant individuals, who tested positive in a solid-phase morphine sIgE antibody assay and could therefore erroneously have been diagnosed as opiate-allergic [57].

The diagnostic management of IDHRs to $\beta$-lactam antibiotics generally relies on SPT, IDT and the quantification of drug-sIgE antibodies. However, as addressed by Blanca et al. [58], in particular cases, BAT provides significant opportunities. Hitherto, 9 studies have investigated BAT as a diagnostic tool in IDHRs to $\beta$-lactam antibiotics, mainly amoxicillin. Compared with the quantification of sIgE antibodies, BAT shows a higher sensitivity (about 50\%) [17, 19, 21, 24, 25] and specificity (approx. 90\%) [17-19, 21]. This indicates that BAT with $\beta$-lactam antibiotics should be considered when skin tests and sIgE serology yield negative or equivocal results. 
Table 2. BAT in immediate $\beta$-lactam and quinolone hypersensitivity

\begin{tabular}{|c|c|c|c|c|c|c|}
\hline Stimulus & Reference test & $\begin{array}{l}\text { Activation } \\
\text { marker }\end{array}$ & $\begin{array}{l}\text { Sensitivity, } \\
\%\end{array}$ & $\begin{array}{l}\text { Specificity, } \\
\%\end{array}$ & $\mathrm{~N}$ & Ref. \\
\hline \multicolumn{7}{|l|}{$\beta$-lactam antibiotics } \\
\hline$\beta$-lactam & $\mathrm{H}$ & CD63 & 50 & 93 & 88 & 17 \\
\hline$\beta$-lactam & $\mathrm{H}+\mathrm{DPT}$ & CD63 & 39 & 93 & 53 & 18 \\
\hline$\beta$-lactam & $\mathrm{H} \pm \mathrm{ST} \pm \mathrm{IgE} \pm \mathrm{DPT}$ & CD63 & 49 & 91 & 110 & 19 \\
\hline \multirow[t]{2}{*}{ Amoxicillin } & $\mathrm{H} \pm \mathrm{ST}$ & CD203c & 52 & 100 & 41 & 20 \\
\hline & & CD63 & 22 & 79 & & \\
\hline$\beta$-lactam & $\mathrm{H}$ & CD63 & 50 & $89-97$ & 262 & 21 \\
\hline \multirow[t]{2}{*}{$\beta$-lactam } & $\mathrm{H} \pm \mathrm{ST} \pm \mathrm{IgE}$ & CD63-CCR3 $^{\mathrm{a}}$ & 55 & 100 & 39 & 22 \\
\hline & & CD63-IgE ${ }^{\mathrm{a}}$ & 53 & & & \\
\hline Amoxicillin & $\mathrm{H}$ & CD63 & 29 & I & $\begin{array}{l}\text { patients: } 14 \\
\text { controls: } 0\end{array}$ & 23 \\
\hline Amoxicillin & $\mathrm{H} \pm \mathrm{ST} \pm \mathrm{DPT}$ & CD63 & 50 & I & $\begin{array}{l}\text { patients: } 61 \\
\text { controls: n.a. }\end{array}$ & 24 \\
\hline Amoxicillin & $\mathrm{H} \pm \mathrm{ST}$ & CD63 & 50 & I & patients: 30 & 25 \\
\hline \multicolumn{7}{|l|}{ Quinolones } \\
\hline Various quinolones & $\mathrm{H}+\mathrm{DPT}$ & CD63 & $0^{\mathrm{b}}$ & 1 & 4 & 26 \\
\hline Various quinolones & $\mathrm{H}+\mathrm{ST} \pm \mathrm{DPT}$ & CD63 & $0^{\mathrm{b}}$ & 100 & 18 & 27 \\
\hline Various quinolones & $\mathrm{H}$ & CD203c & 100 & 100 & 5 & 28 \\
\hline Various quinolones & $\mathrm{H} \pm \mathrm{DPT}$ & CD63 & 71 & I & 73 & 29 \\
\hline Various quinolones & $\mathrm{H} \pm \mathrm{DPT}$ & CD203c & n.a. & 100 & 34 & 30 \\
\hline \multicolumn{7}{|c|}{$\begin{array}{l}\text { DPT with moxifloxacin was only performed in control individuals to establish tolerance status. } \mathrm{H}=\mathrm{History} \text {; } \\
\mathrm{N}=\text { number of patients and control individuals; } \mathrm{n} . \mathrm{a} .=\text { not available; } \mathrm{ST}=\text { skin test. } \\
\text { a Different selection marker. }{ }^{\mathrm{b}} \text { Note that all CD63-based assays yielded entirely negative results, except in the } \\
\text { Aranda series [29]. }\end{array}$} \\
\hline
\end{tabular}

Another illustration of the potential of BAT is in allergy to quinolones. These drugs can cause severe allergies, with moxifloxacin being the most important culprit [59]. BAT can be of extra value, since the diagnosis of quinolone allergy can pose a significant challenge. First, there are still no well-validated drug-sIgE antibody assays readily available and controversy has arisen about the specificity of some methods [60]. Furthermore, quinolone SPT and IDT are associated with uncertainty, and positive skin responses have been reported in individuals without overt quinolone allergy. For example, we observed that moxifloxacin skin testing yielded a positive predictive value of $36 \%$ and a negative predictive value of $25 \%$ [61]. Studies on BAT with quinolones (table 2) reveal quite divergent but highly interesting findings, mainly with respect to the sensitivity of the test. All CD63-based assays yielded negative results $[26,27]$, except for in the study of Aranda et al. [29]. This suggests that fluoroquinolones might trigger basophil activation that cannot readily be depicted by traditional CD63-based assays. Al- ternatively, the more consistent results with CD203c upregulation $[28,30]$ could indicate that mediator release in response to quinolones could result from alternative degranulation pathways $[62,63]$.

IDHRs to NSAIDs are extremely common and it is generally accepted that a large majority of these reactions are independent from IgE/FceRI cross-linking but correspond to a pharmacological mechanism caused by the inhibition of cyclo-oxygenase (COX)-1, which finally results in the depletion of prostaglandin E2 with unstrained synthesis of cysteinyl leukotrienes and mediator release from basophils, mast cells and eosinophils. Consequently, as addressed in other studies [64], BAT generally displays insufficient sensitivity (about 20-40\%) to diagnose IDHRs to NSAID hypersensitivity. However, a minority of IDHRs to NSAIDs appear to be 'genuine' IgE-mediated reactions, and, in such cases, patients appear to react exclusively to a single NSAID family. So far, 5 publications have reported on BAT in selective hypersensitivity to pyrazolones [31, 32, 36, 43, 44], with BAT yielding a 
Table 3. BAT in immediate NSAID hypersensitivity

\begin{tabular}{|c|c|c|c|c|c|c|}
\hline Stimulus & $\begin{array}{l}\text { Reference } \\
\text { test }\end{array}$ & $\begin{array}{l}\text { Activation } \\
\text { marker }\end{array}$ & $\begin{array}{l}\text { Sensitivity, } \\
\%\end{array}$ & $\begin{array}{l}\text { Specificity, } \\
\%\end{array}$ & $\mathrm{~N}$ & Ref. \\
\hline Metamizol & $\mathrm{H} \pm \mathrm{DPT}$ & CD63 & 42 & 100 & 56 & 31 \\
\hline Metamizol & $\mathrm{H}$ & CD63 & 42.3 & 100 & 56 & 32 \\
\hline Various NSAIDs & $\mathrm{H} \pm \mathrm{DPT}$ & CD63 & $15-55$ & $74-100$ & 90 & 33 \\
\hline Diclofenac & $\mathrm{H}$ & CD63 & \multicolumn{2}{|c|}{$\begin{array}{l}\text { No significant difference } \\
\text { in CD63 expression between } \\
\text { patients and controls } \\
\text { (IgE-independent basophil } \\
\text { degranulation) }\end{array}$} & 26 & 34 \\
\hline Various NSAIDs & $\mathrm{H}$ & CD63 & 43 & 100 & 72 & 35 \\
\hline Pyrazolones & $\mathrm{H} \pm \mathrm{IDT} \pm \mathrm{DPT}$ & CD63 & 55 & 86 & 107 & 36 \\
\hline$\overline{\mathrm{ASA}}$ & $\mathrm{H} \pm \mathrm{DPT}$ & $\begin{array}{l}\text { CD63 } \\
\text { CD203c }\end{array}$ & $\begin{array}{l}34 \\
17\end{array}$ & $\begin{array}{r}79 \\
100\end{array}$ & 42 & 37 \\
\hline Diclofenac & & $\begin{array}{l}\text { CD63 } \\
\text { CD203c }\end{array}$ & $\begin{array}{l}17 \\
22\end{array}$ & $\begin{array}{r}92 \\
100\end{array}$ & & \\
\hline$\overline{\mathrm{ASA}}$ & $\mathrm{H} \pm \mathrm{DPT}$ & $\begin{array}{l}\text { CD63 } \\
\text { CD203c }\end{array}$ & $\begin{array}{l}30 \\
70 \\
\end{array}$ & $\begin{array}{l}40 \\
45 \\
\end{array}$ & 20 & 38 \\
\hline Diclofenac & $\mathrm{H} \pm \mathrm{DPT}$ & CD63 & 0 & I & 22 & 39 \\
\hline Aspirin & $\mathrm{H}+\mathrm{DPT}$ & CD63 & $\begin{array}{l}80^{\mathrm{a}} \\
78^{\mathrm{b}}\end{array}$ & $\begin{array}{l}83^{\mathrm{a}} \\
50^{\mathrm{b}}\end{array}$ & 59 & 40 \\
\hline Various NSAIDs & $\mathrm{H}+\mathrm{DPT}$ & CD63 & 61 & 91 & 29 & 41 \\
\hline Various NSAIDs & $\mathrm{H}$ & CD63 & 37 & 90 & 80 & 42 \\
\hline Metamizol & $\mathrm{H}$ & CD63 & 0 & I & $\begin{array}{l}\text { patients: } 6 \\
\text { controls: } 0\end{array}$ & 43 \\
\hline Metamizol & $\mathrm{H} \pm \mathrm{ST}$ & CD63 & 70 & 100 & 30 & 44 \\
\hline Various NSAIDs & $\mathrm{H} \pm \mathrm{DPT}$ & CD63 & 100 & 20 & 91 & 45 \\
\hline
\end{tabular}

ASA = Acetylsalicylic acid; $\mathrm{H}=$ history; $\mathrm{N}=$ number of patients and control individuals; ST = skin test.

${ }^{a}$ For anaphylaxis. ${ }^{b}$ For asthma/rhinoconjunctivitis.

Table 4. BAT in immediate hypersensitivity to RCM

\begin{tabular}{lllllll}
\hline Stimulus & $\begin{array}{l}\text { Reference } \\
\text { test }\end{array}$ & $\begin{array}{l}\text { Activation } \\
\text { marker }\end{array}$ & $\begin{array}{l}\text { Sensitivity, } \\
\%\end{array}$ & $\begin{array}{l}\text { Specificity, } \\
\%\end{array}$ & N & Ref. \\
\hline Various RCM & H + ST & CD63 & 100 & 100 & $\begin{array}{l}\text { patients: } 3 \\
\text { controls: } \text { n.a. }\end{array}$ & 46 \\
\hline Various RCM & H \pm ST & CD63 & $46-62 \%^{\mathrm{a}}$ & $89-100 \%^{\mathrm{a}}$ & 40 & 47 \\
\hline Various RCM & H \pm ST \pm DPT & CD63 & 63 & 100 & 28 & 48 \\
\hline
\end{tabular}

$\mathrm{H}=$ History; $\mathrm{N}=$ number of patients and control individuals; $\mathrm{n} . \mathrm{a}$. = not available; $\mathrm{ST}$ = skin test.

a Depending on the cut-off value.

sensitivity of $42-70 \%$ and a specificity of $86-100 \%$; 1 study showed a significantly lower sensitivity, thereby contradicting the other studies [43].

IDHRs to RCM have been described, but their prevalence is low and is estimated at $0.02 \%$ for nonionic RCM and $0.4 \%$ for ionic RCM. Direct histamine release by means of nonspecific RCM binding to surface receptors on mast cells or basophils and indirect cell activation by means of the complement or kinin cascade outnumber the genuine IgE-mediated reactions that might be overlooked with skin testing $[47,65]$. These reactions are believed to account for approximately $4 \%$ of the IDHRs to 
RCM. Up to now, 3 studies have reported on the value of BAT in the diagnosis of IDHRs to RCM [46-48]. These studies demonstrate a sensitivity of 46-63\%, depending on the chosen threshold, and a specificity of $89-100 \%$. Furthermore, it seems that the results of BAT and skin testing are complementary [47].

\section{Commentaries and Perspectives}

Already from the earliest days of BAT, it was obvious that this technique would become an asset in the allergologic diagnostic instrumentation. Actually, the diagnostic utility of BAT (and to a lesser extent, HistaFlow) has repeatedly been demonstrated in both IgE-mediated allergy (e.g. aeroallergens, food, hymenoptera venom and Hevea latex) and autoimmune urticaria, a condition that results from the production of autoantibodies against FceRI or IgE itself [2]. However, the utility and usefulness of BAT/ HistaFlow needs to be reevaluated thoroughly, in view of the difficulties inherent to the correct preparation and storage of allergen extracts, optimizing and standardizing stimulation conditions and also the potential of alternative, more easily accessible diagnostic instruments such as component-resolved diagnosis, currently only available for food [66] and hymenoptera venom [67]. Conse- quently, at present, the diagnostic application of BAT/ HistaFlow has mainly to be sought in the domain of IDHRs, particularly when diagnosis cannot be established by other means. However, additional, collaborative, large-scale studies are needed to verify whether BAT/ HistaFlow holds promise as well as to optimize and harmonize protocols, avoid the instigation of cynicism and skepticism and enable and justify the introduction of these tests to routine diagnostic application. Some of the requirements of these validation studies have recently been detailed elsewhere [68]. Clearly, these studies should adopt standardized and harmonized clinical and laboratory protocols, in order to avoid erroneous conclusions that might impede appropriate clinical validation of the assays.

\section{Acknowledgement}

V.S. is a Clinical Researcher at the Research Foundation Flanders (FWO: 1700614N). D.G.E. is a Senior Clinical Researcher at the FWO $(1800614 \mathrm{~N})$.

\section{Disclosure Statement}

The authors declare there were no conflicts of interest.

\section{References}

1 Knol EF, Mul FP, Jansen H, Calafat J, Roos D: Monitoring human basophil activation via CD63 monoclonal antibody 435. J Allergy Clin Immunol 1991;88:328-338.

2 Ebo DG, Bridts CH, Hagendorens MM, Aerts NE, De Clerck LS, Stevens WJ: Basophil activation test by flow cytometry: present and future applications in allergology. Cytometry B Clin Cytom 2008;74:201-210.

3 Sabato V, Verweij MM, Bridts $\mathrm{CH}$, LeviSchaffer F, Gibbs BF, De Clerck LS, Schiavino D, Ebo DG: CD300a is expressed on human basophils and seems to inhibit IgE/FceRIdependent anaphylactic degranulation. $\mathrm{Cy}$ tometry B Clin Cytom 2012;82:132-138.

4 Ebo DG, Dombrecht EJ, Bridts CH, Aerts NE, De Clerck LS, Stevens WJ: Combined analysis of intracellular signalling and immunophenotype of human peripheral blood basophils by flow cytometry: a proof of concept. Clin Exp Allergy 2007;37:1668-1675.

5 Verweij MM, Sabato V, Nullens S, Bridts CH, De Clerck LS, Stevens WJ, Ebo DG: STAT5 in human basophils: IL-3 is required for its FceRI-mediated phosphorylation. Cytometry B Clin Cytom 2012;82:101-106.
6 Ebo DG, Bridts CH, Mertens CH, Hagendorens MM, Stevens WJ, De Clerck LS: Analyzing histamine release by flow cytometry (HistaFlow): a novel instrument to study the degranulation patterns of basophils. J Immunol Methods 2012;375:30-38.

7 Bridts CH, Sabato V, Mertens C, Hagendorens MM, De Clerck LS, Ebo DG: Flow cytometric allergy diagnosis: basophil activation techniques. Methods Mol Biol 2014;1192: 147-159.

8 Abuaf N, Rajoely B, Ghazouani E, Levy DA, Pecquet C, Chabane H, Leynadier F: Validation of a flow cytometric assay detecting in vitro basophil activation for the diagnosis of muscle relaxant allergy. J Allergy Clin Immunol 1999;104(2 Pt 1):411-418.

9 Monneret G, Benoit Y, Debard AL, Gutowski MC, Topenot I, Bienvenu J: Monitoring of basophil activation using CD63 and CCR 3 in allergy to muscle relaxant drugs. Clin Immunol 2002;102:192-199.

10 Sudheer PS, Hall JE, Read GF, Rowbottom AW, Williams PE: Flow cytometric investigation of peri-anaesthetic anaphylaxis using CD63 and CD203c. Anaesthesia 2005;60:251-256.
11 Kvedariene V, Kamey S, Ryckwaert Y, Rongier M, Bousquet J, Demoly P, Arnoux B: Diagnosis of neuromuscular blocking agent hypersensitivity reactions using cytofluorimetric analysis of basophils. Allergy 2006;61: 311-315.

12 Ebo DG, Bridts CH, Hagendorens MM, Mertens CH, De Clerck LS, Stevens WJ: Flowassisted diagnostic management of anaphylaxis from rocuronium bromide. Allergy 2006;61:935-939.

13 Sainte-Laudy J, Orsel I: Interest of a new flow cytometric protocol applied to diagnosis and prevention of anaesthetic accidents induced by neuromuscular blockers. Rev Fr Allergol 2008;48:470-475.

14 Leysen J, Bridts CH, De Clerck LS, Vercauteren M, Lambert J, Weyler JJ, Stevens WJ, Ebo DG: Allergy to rocuronium: from clinical suspicion to correct diagnosis. Allergy 2011; 66:1014-1019.

15 Hagau N, Gherman-Ionica N, Sfichi M, Petrisor C: Threshold for basophil activation test positivity in neuromuscular blocking agents hypersensitivity reactions. Allergy Asthma Clin Immunol 2013;9:42-49. 
16 Uyttebroek AP, Sabato V, Leysen J, Bridts $\mathrm{CH}$, De Clerck LS, Ebo DG: Flowcytometric diagnosis of atracurium-induced anaphylaxis. Allergy 2014;69:1324-1332.

17 Sanz ML, Gamboa PM, Antepara I, Uasuf C, Vila L, Garcia-Aviles C, Chazot M, De Weck AL: Flow cytometric basophil activation test by detection of CD63 expression in patients with immediate-type reactions to betalactam antibiotics. Clin Exp Allergy 2002;32:277286.

18 Gamboa PM, Garcia-Aviles MC, Urrutia I, Antepara I, Esparza R, Sanz ML: Basophil activation and sulfidoleukotriene production in patients with immediate allergy to betalactam antibiotics and negative skin tests. J Investig Allergol Clin Immunol 2004;14:278-283.

19 Torres MJ, Padial A, Mayorga C, Fernandez T, Sanchez-Sabate E, Cornejo-Garcia JA, Antunez C, Blanca M: The diagnostic interpretation of basophil activation test in immediate allergic reactions to betalactams. Clin Exp Allergy 2004;34:1768-1775.

20 Abuaf N, Rostane H, Rajoely B, Gaouar H, Autegarden JE, Leynadier F, Girot R: Comparison of two basophil activation markers $\mathrm{CD} 63$ and CD203c in the diagnosis of amoxicillin allergy. Clin Exp Allergy 2008;38:921928.

21 De Weck AL, Sanz ML, Gamboa PM, Aberer W, Blanca M, Correia S, Erdman S, Jermann JM, Kanny G, Kowalski M, Mayorga L, Medrala W, Merk A, Sturm GJ, Sainte-Laudy J, Schneider MS, Sczczeklik A, Weber JM, Wedi A: Nonsteroidal anti-inflammatory drug hypersensitivity syndrome. A multicenter study. I. Clinical findings and in vitro diagnosis. J Investig Allergol Clin Immunol 2009;19:355369.

22 Eberlein B, Leon S, Darsow IU, Rueff F, Behrendt $\mathrm{H}$, Ring J: A new basophil activation test using CD63 and CCR3 in allergy to antibiotics. Clin Exp Allergy 2010;40:411-418.

23 Garcia-Ortega P, Marin A: Usefulness of the basophil activation test (BAT) in the diagnosis of life-threatening drug anaphylaxis. Allergy 2010;65:1204-9995.

24 Torres MJ, Ariza A, Fernandez J, Moreno E, Laguna JJ, Montanez MI, Ruiz-Sanchez AJ, Blanca M: Role of minor determinants of amoxicillin in the diagnosis of immediate allergic reactions to amoxicillin. Allergy 2010; 65:590-596.

25 Torres MJ, Romano A, Blanca-Lopez N, Dona I, Canto G, Ariza A, Aranda A, Montanez MI, Mayorga C, Blanca M: Immunoglobulin Emediated hypersensitivity to amoxicillin: in vivo and in vitro comparative studies between an injectable therapeutic compound and a new commercial compound. Clin Exp Allergy 2011;41:1595-1601.

26 Seitz CS, Brocker EB, Trautmann A: Diagnostic testing in suspected fluoroquinolone hypersensitivity. Clin Exp Allergy 2009;39: 1738-1745.
27 Lobera T, Audicana MT, Alarcon E, Longo N, Navarro B, Munoz D: Allergy to quinolones: low cross-reactivity to levofloxacin. J Investig Allergol Clin Immunol 2010;20:607-611.

28 Ben SB, Berard F, Bienvenu J, Nicolas JF, Rozieres A: Usefulness of basophil activation tests for the diagnosis of IgE-mediated allergy to quinolones. Allergy 2010;65:535-536.

29 Aranda A, Mayorga C, Ariza A, Dona I, Rosado A, Blanca-Lopez N, Andreu I, Torres MI: In vitro evaluation of IgE-mediated hypersensitivity reactions to quinolones. Allergy 2011; 66:247-254.

30 Rouzaire P, Nosbaum A, Denis L, Bienvenu F, Berard F, Cozon G, Bienvenu J: Negativity of the basophil activation test in quinolone hypersensitivity: a breakthrough for provocation test decision-making. Int Arch Allergy Immunol 2012;157:299-302.

31 Gamboa PM, Sanz ML, Caballero MR, Antepara I, Urrutia I, Jauregui I, Gonzalez G, Dieguez I, De Weck AL: Use of CD63 expression as a marker of in vitro basophil activation and leukotriene determination in metamizol allergic patients. Allergy 2003;58:312-317.

32 Sanz ML, Garcia MC, Caballero MR, Dieguez I, Gamboa PM: Basophil activation test in the diagnosis of allergy to medicines. An Sist Sanit Navar 2003;26(suppl 2):39-47.

33 Gamboa P, Sanz ML, Caballero MR, Urrutia I, Antepara I, Esparza R, De Weck AL: The flow-cytometric determination of basophil activation induced by aspirin and other nonsteroidal anti-inflammatory drugs (NSAIDs) is useful for in vitro diagnosis of the NSAID hypersensitivity syndrome. Clin Exp Allergy 2004;34:1448-1457.

34 Malbran A, Yeyati E, Rey GL, Galassi N: Diclofenac induces basophil degranulation without increasing CD63 expression in sensitive patients. Clin Exp Immunol 2007;147: 99-105.

35 Rodriguez-Trabado A, Camara-Hijon C, Ramos-Cantarino A, Porcel-Carreno SL, Jimenez-Timon S, Pereira-Navarro G, Hernandez-Arbeiza FJ, Fernandez-Pereira L: Basophil activation test for the in vitro diagnosis of nonsteroidal anti-inflammatory drug hypersensitivity. Allergy Asthma Proc 2008;29: 241-249.

36 Gomez E, Blanca-Lopez N, Torres MJ, Requena G, Rondon C, Canto G, Blanca M, Mayorga C: Immunoglobulin E-mediated immediate allergic reactions to dipyrone: value of basophil activation test in the identification of patients. Clin Exp Allergy 2009;39:12171224.

37 Bavbek S, Ikinciogullari A, Dursun AB, Guloglu D, Arikan M, Elhan AH, Misirligil Z: Upregulation of $\mathrm{CD} 63$ or $\mathrm{CD} 203 \mathrm{c}$ alone or in combination is not sensitive in the diagnosis of nonsteroidal anti-inflammatory drug intolerance. Int Arch Allergy Immunol 2009; 150:261-270.
38 Celik GE, Schroeder JT, Hamilton RG, Saini SS, Adkinson NF: Effect of in vitro aspirin stimulation on basophils in patients with aspirin-exacerbated respiratory disease. Clin Exp Allergy 2009;39:1522-1531.

39 Harrer A, Lang R, Grims R, Braitsch M, Hawranek T, Aberer W, Vogel L, Schmid W, Ferreira F, Himly M: Diclofenac hypersensitivity: antibody responses to the parent drug and relevant metabolites. PLoS One 2010;5:e13707.

40 Korosec P, Mavsar N, Bajrovic N, Silar M, Mrhar A, Kosnik M: Basophil responsiveness and clinical picture of acetylsalicylic acid intolerance. Int Arch Allergy Immunol 2011; 155:257-262.

41 Kim MS, Cho YJ: Flow cytometry-assisted basophil activation test as a safe diagnostic tool for aspirin/NSAID hypersenstivity. Allergy Asthma Immunol Res 2012;4:137-142.

42 Abuaf N, Rostane H, Barbara J, Toly-Ndour C, Gaouar H, Mathelier-Fusade P, Leynadier F, Frances C, Girot R: Comparison of CD63 upregulation induced by NSAIDs on basophils and monocytes in patients with NSAID hypersensitivity. J Allergy (Cairo) 2012;2012 580873.

43 Couto M, Gaspar A, Piedade S, Arede C, Menezes M, Sousa MJ, Sousa G, Morais-Almeida M: IgE-mediated metamizol allergy and the usefulness of the cellular allergen stimulation test. Eur Ann Allergy Clin Immunol 2012;44:113-116.

44 Hagau N, Longrois D, Petrisor C: Threshold for positivity and optimal dipyrone concentration in flow cytometry-assisted basophil activation test. Allergy Asthma Immunol Res 2013;5:383-388.

45 Ariza A, Fernandez TD, Dona I, Aranda A, Blanca-Lopez N, Melendez L, Canto G, Blanca M, Torres MJ, Mayorga C: Basophil activation after nonsteroidal anti-inflammatory drugs stimulation in patients with immediate hypersensitivity reactions to these drugs. $\mathrm{Cy}$ tometry A 2014;85:400-407.

46 Trcka J, Schmidt C, Seitz CS, Brocker EB, Gross GE, Trautmann A: Anaphylaxis to iodinated contrast material: nonallergic hypersensitivity or IgE-mediated allergy? AJR Am J Roentgenol 2008;190:666-670.

47 Pinnobphun P, Buranapraditkun S, Kampitak T, Hirankarn N, Klaewsongkram J: The diagnostic value of basophil activation test in patients with an immediate hypersensitivity reaction to radiocontrast media. Ann Allergy Asthma Immunol 2011;106:387-393.

48 Salas M, Gomez F, Fernandez TD, Dona I, Aranda A, Ariza A, Blanca-Lopez N, Mayorga C, Blanca M, Torres MJ: Diagnosis of immediate hypersensitivity reactions to radiocontrast media. Allergy 2013;68:1203-1206.

49 Ebo FH, Piel GC, Conraads V, Stevens WJ IgE-mediated anaphylaxis after first intravenous infusion of cyclosporine. Ann Allergy Asthma Immunol 2001;87:243-245.
In vitro Diagnosis of Immediate Drug Hypersensitivity
Int Arch Allergy Immunol 2015;168:3-12 DOI: $10.1159 / 000440663$ 
50 Longo N, Gamboa PM, Gastaminza G, Audicana MT, Antepara I, Jauregui I, Sanz ML: Diagnosis of clavulanic acid allergy using basophil activation and leukotriene release by basophils. J Investig Allergol Clin Immunol 2008; 18:473-475.

51 Ebo DG, Bridts CH, Stevens WJ: IgE-mediated anaphylaxis from chlorhexidine: diagnostic possibilities. Contact Dermatitis 2006;55: 301-302.

52 Ebo DG, Wets RD, Spiessens TK, Bridts CH Stevens WJ: Flow-assisted diagnosis of anaphylaxis to patent blue. Allergy 2005;60:703704.

53 Apostolou E, Deckert K, Puy R, Sandrini A, de Leon MP, Douglass JA, Rolland JM, O'hehir RE: Anaphylaxis to Gelofusine confirmed by in vitro basophil activation test: a case series. Anaesthesia 2006;61:264-268.

54 Ebo DG, Schuerwegh A, Stevens WJ: Anaphylaxis to starch. Allergy 2000;55:1098-1099.

55 Cop N, Uyttebroek AP, Sabato V, Bridts CH, De Clerck LS, Ebo DG: Flow cytometric analysis of drug-induced basophil histamine release. Cytometry B Clin Cytom 2015, Epub ahead of print.

56 Leysen J, De Witte L, Sabato V, Faber M, Hagendorens M, Bridts C, De Clerck L, Ebo D: IgE-mediated allergy to pholcodine and cross-reactivity to neuromuscular blocking agents: lessons from flow cytometry. Cytometry B Clin Cytom 2013;84:65-70.
57 Van Gasse AL, Hagendorens MM, Sabato V, Bridts CH, De Clerck LS, Ebo DG: IgE poppy seed and morphine: all that glitters is not gold. J Allergy Clin Immunol Pract 2014, Epub ahead of print.

58 Blanca M, Romano A, Torres MJ, Fernandez J, Mayorga C, Rodriguez J, Demoly P, Bousquet PJ, Merk HF, Sanz ML, Ott H, Atanaskovic-Markovic M: Update on the evaluation of hypersensitivity reactions to betalactams. Allergy 2009;64:183-193.

59 Jones SC, Budnitz DS, Sorbello A, Mehta H: US-based emergency department visits for fluoroquinolone-associated hypersensitivity reactions. Pharmacoepidemiol Drug Saf 2013;22:1099-1106.

60 Baldo BA, Pham NG: Drug Allergy: Clinical Aspects, Diagnosis, Mechanisms, StructureActivity Relationships. New York, Springer, 2013.

61 Uyttebroek AP, Sabato V, Bridts CH, De Clerck LS, Ebo DG: Moxifloxacin hypersensitivity: uselessness of skin testing. J Allergy Clin Immunol Pract 2015;3:443-445.
62 MacGlashan D Jr: Marked differences in the signaling requirements for expression of CD203c and CD11b versus CD63 expression and histamine release in human basophils. Int Arch Allergy Immunol 2012;159:243-252.

63 MacGlashan DW Jr: Basophil activation testing. J Allergy Clin Immunol 2013;132:777-787.

64 Song WJ, Chang JS: Recent applications of basophil activation tests in the diagnosis of drug hypersensitivity. Asia Pac Allergy 2013;3: 266-280

65 Philipse E, Sabato V, Bridts C, De CL, Ebo D: Basophil activation in the diagnosis of lifethreatening hypersensitivity reaction to iodinated contrast media: a case report. Acta Clin Belg 2013;68:140-142.

66 Faber M, Sabato V, De WL, Van GA, Hagendorens MM, Leysen J, Bridts $\mathrm{CH}$, De Clerck LS, Ebo DG: State of the art and perspectives in food allergy. I. Diagnosis. Curr Pharm Des 2014;20:954-963.

67 Ebo DG, Van Vaerenbergh M, de Graaf DC, Bridts $\mathrm{CH}$, De Clerck LS, Sabato V: In vitro diagnosis of hymenoptera venom allergy and further development of component resolved diagnostics. Exp Rev Clin Immunol 2014;10: 375-384.

68 Uyttebroek AP, Sabato V, Bridts CH, Ebo DG: In vitro diagnosis of immediate IgE-mediated drug hypersensitivity: warnings and (unmet) needs. Immunol Allergy Clin North Am 2014; 34:681-689. 